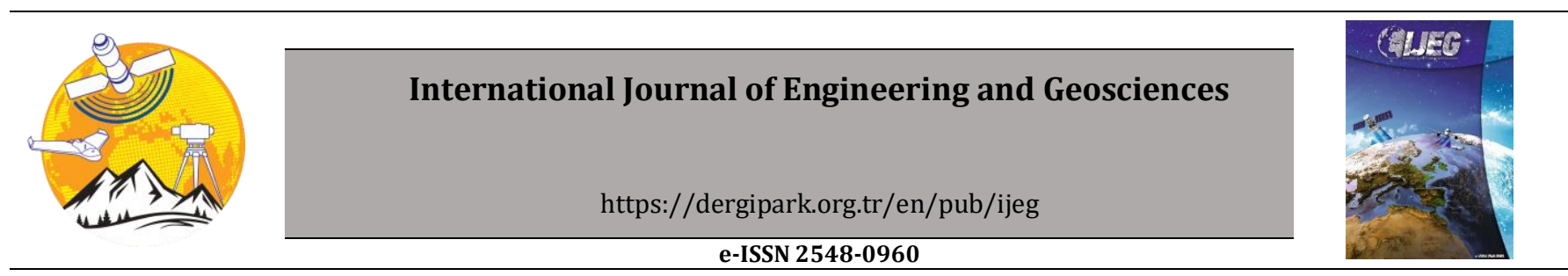

\title{
Investigating changes in land cover in high-density settlement areas by protected scenario
}

\author{
Ahmet Emir Yakup*1@, İsmail Ercüment Ayazlı 2 (1) \\ ${ }^{1}$ Hitit University, Osmancik Vocational School, Department of Architecture and Urban Planning, Corum, Turkey \\ 2Sivas Cumhuriyet University, Engineering Faculty, Department of Geomatics Engineering, Sivas, Turkey
}

\author{
Keywords \\ GIS \\ Urban Growth \\ SLEUTH \\ Cellular Automata \\ Land Management
}

\begin{abstract}
Uncontrolled urban growth is one of the most prominent problems in modern urbanism and planning. Rapid urbanization and population growth cause changes in land cover. In addition, determining the effects of these changes is essential in terms of sustainable urban management policies. Urban growth is a complex, dynamic structure that initiates changes in land cover. For this reason, simulation models are used extensively in planning studies. In this study, land cover simulation of the Sancaktepe district in Istanbul was carried out with the SLEUTH model based on cellular automata (CA). The study aims to identify the damage caused by uncontrolled urbanization. In this context, a scenario was created based on the assumption that forests will be protected based on the changes in land cover that occurred between 19612014. The data used in the model were generated from cadastral maps on a parcel basis. For this purpose, four-period data sets (1961-1992-2001-2014) were prepared between 19612014 . According to the simulation results, $82 \%$ of agricultural land, $2 \%$ of forest land and $84 \%$ of open land will probably be converted into residential use. According to the results, it has been determined that almost all of the open and agricultural land in the towns of Pasakoy and Samandira in the district of Sancaktepe have been converted into residential areas. According to the prediction that the changes in current land cover will continue, no change is expected in forests, while it has been determined that the potential to transform agricultural land and open land into settlement areas is quite high.
\end{abstract}

\section{INTRODUCTION}

Population growth leads to urban growth, which leads to the expansion of cities and the destruction of agro-forest land. Therefore, it is becoming increasingly difficult to obtain the requirements for essential nutrients and clean air.

With the growth of cities, changes in land cover cause people to live in unhealthy conditions day by day. The growth in population, especially after 1950, witnessed the beginning of rural-urban migration and the urbanization movement across the world (Satterthwaite, 2005). The destruction of the environment has brought areas of unplanned land, settlement irregularity, and problems in planning and management. The transformation of forests and agricultural land into urban, residential areas results in excessive pressure on natural resources and poses challenges for environmental management (EEA, 2016). For this reason, controlling the process of urbanization is important for achieving the goals of policies of sustainable development.

Several models have been generated to understand urban systems and to control urban growth. The initial models were in a radial and linear form, therefore, they were insufficient for modelling the complex and dynamic structure of cities (Ayazli, 2019; Foot, 2017).

Today's advancements in computer technologies have made it possible to model the complex and dynamic structure of cities with simulation. Models estimate land cover changes based on historical data, economic data, physical constraints, or logical transition rules (Verburg, 2006). In urban modelling techniques, such as artificial neural networks (ANN), agent-based modelling (ABM) and cellular automata (CA) are the most suitable for modelling the complex and dynamic structure of cities (Batty, 2009; Grimm et al., 2005; Tobler, 1970).

One of the most widely used CA-based models in research is the SLEUTH urban growth model. SLEUTH is a model that simulates urban growth dynamics and land cover transformations. It is an open-source software

\footnotetext{
* Corresponding Author

*(emiryakup@hitit.edu.tr) ORCID ID 0000 - 0002 - 1789 - 4448

(eayazli@cumhuriyet.edu.tr) ORCID ID 0000 - 0003 - 0782 - 5366
}

Research Article / DOI: 10.26833/ijeg.850247
Cite this article

Yakup A E \& Ayazli I E (2022). Investigating changes in land cover in high-density settlement areas by protected scenario. International Journal of Engineering and Geosciences, 7(1), 01-08 
developed with the C programming language (Gigalopolis, 2020). The model consists of three processing stages: test, calibration and predict. The compliance of the input data with the model standards is checked during the test phase. The parameters of the growth rules in the model are calculated during the calibration phase. Finally, in the predict stage, land cover simulations of the area are created.

In studies conducted with SLEUTH, urban growth and land cover simulations of the world's leading cities have been successfully produced. The model was first applied in San Francisco (Clarke et al., 1997) and the Washington-Baltimore (Clarke \& Gaydos, 1998) region. In the following period, a series of studies were carried out in Santa Barbara to determine the technical development of the urbanization process (Candau \& Clarke, 2000; Goldstein et al., 2004; Herold et al., 2003). It was first implemented in Europe by Silva and Clarke (2005; 2002) for the Lisbon and Porto metropolitan areas of Portugal. On the other hand, SLEUTH has the highest number of applications in China. Simulations were produced under the ongoing conditions of the city or under alternative scenarios to evaluate the impact and extent of urbanization in rapidly growing cities such as Chongqing (Huanga et al., 2008), Beijing (Yi \& He, 2009), Lanzhou (Xie et al., 2010) and Nanjing (Zhang et al., 2010). The model has also been extensively used in mapping and imaging urban growth and land cover changes in other countries, for example, Istanbul, Turkey (Ayazli et al., 2015), Cape Town, South Africa (Watkiss, 2008), Muscat, Oman (Al-Awadhi, 2007) and Hyderabad, India (Gandhi \& Suresh, 2012).

Studies have shown that CA-based models are useful and reliable in obtaining information about the dynamics of place and time of a complex system such as a city (Bihamta et al., 2014; Chaudhuri \& Clarke, 2013; Clarke \& Gaydos, 1998; Dennunzio et al., 2012; Di Lena \& Margara, 2008). For this reason, the SLEUTH model, which is a CA-based model that simulates urban growth and land cover using historical data, was chosen for the simulation model of Sancaktepe.

Simulation models produced in the literature often use low-resolution data (Akin et al., 2014; Bihamta et al., 2014; Jantz et al., 2004; Saadani et al., 2020; Sandamali et al., 2018). To improve model accuracy, high-resolution cadastral data were used in this study.

At the first stage of the model, data from 1961, 1992, 2001 and 2014 were obtained from The Land Registry and Cadaster IInd Regional Directorate, and growth dynamics were examined more accurately in the geographic information system (GIS) environment. According to the findings, a scenario was created with the prediction that trends of land cover change in the region will continue in the future. In previous studies of Sancaktepe, attention was drawn to the pressure of urbanization on forests (Ayazli et al., 2019; Ayazli \& Baslik, 2016). In this study, a new scenario was created based on the transformation rate in forests according to temporal change analysis between 1961-2014. With the scenario created in this context, and by examining past behaviours in changes in land cover, it was determined that $87 \%$ of forests were protected. For this reason, considering that the forests in the study area will be protected, the zoning movements, natural protection zones and places with high agricultural potential in the region are arranged within the zoning data, while the possible effects of urban growth are investigated. Furthermore, to measure the success of the generated scenario, the predicted land cover image for 2020 was rectified and calculated using kappa statistics to determine its accuracy, by comparing actual highresolution land cover images.

In this study, answers to the following questions were investigated:

- How do possible urban growth trends in Sancaktepe affect changes in land cover?

- How does the direction and speed of urban growth change according to the scenario produced?

- How will the land cover of the Sancaktepe region change in 2030, 2050 and 2070 ?

\section{STUDY AREA}

The district of Sancaktepe is located on the Anatolian side of Istanbul. The district of Cekmekoy is to the north of Sancaktepe. Kartal and Maltepe are located to the south, Sultanbeyli and Pendik to the east, and Umraniye and Atasehir to the west (Fig-1). It was formed with the merging of the towns of Samandira, Sarıgazi and Yenidogan following the law that came into force in 2008. Consisting of 19 neighbourhoods, the district of Sancaktepe has an area of $62.41 \mathrm{~km}^{2}$ (Sancaktepe, 2020).

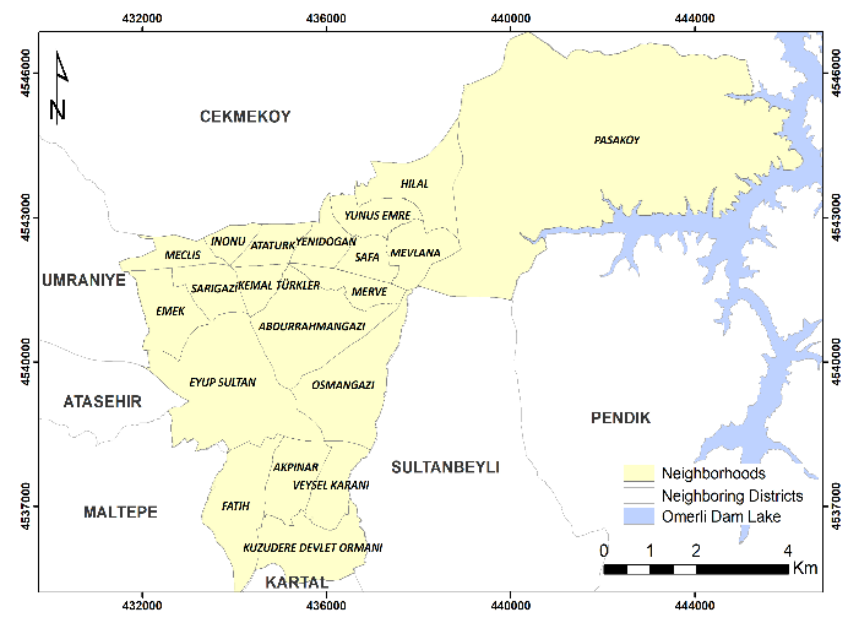

Figure 1. Sancaktepe's administrative borders.

According to data from the Turkish Statistical Institute, the population of Sancaktepe in 2008 was 229,093 , growing to 329,788 in 2014 , and 436,733 in 2019; an increase of $90 \%$ compared to 2008 (TUIK, 2020).

The importance of the region, which is an extremely sensitive residential area due to its basin nature, is increasing day by day due to transport opportunities. The Pasakoy region, which was specified as unsuitable for settlement throughout the region, is located within the short-range protection zone and in the absolute protection zone of the stream. However, as a result of rapid population growth and intense urbanization 
activities, urbanization has almost reached the basin border (Aydin, 2010; Sancaktepe, 2010).

\section{MATERIALS AND METHOD}

\subsection{Cellular Automata}

The CA, one of the mathematical modelling methods, is used as an effective tool in the creation of complex place and temporal process models.

The CA concept consists of five basic components. These are lattice, state set, neighbourhood relationship (determined by the nearest neighbouring cells), transformation rules and time. Cells are the smallest units that are adjacent to each other. The cells come together to form the grid network. Every cell has a state. An infinite number of state types can be specified in the state set. But a cell can only take one state at a time. The situations can change according to the transformation rules determined by the neighbourhood function (Benenson \& Torrens, 2004).

CA is a suitable method for simulating urban systems because it is directly compatible with Raster GIS and is dynamic; state transitions intuitively mimic the temporal dynamics of urban change (Clarke et al., 1997).

\subsection{SLEUTH}

SLEUTH is an open-source software developed by Keith Clarke, based on CA, simulating urban growth dynamics and land cover transformations. The name of the model is derived from the initials of the input data: Slope, Landcover, Excluded, Urban, Transportation, and Hillshade.

The model has three processing stages i.e. test, calibration and prediction stages. During the test phase, the suitability of the input data is questioned. If it is successful, the calibration process is started. The calibration phase is particularly important in capturing the characteristics of urban growth and to successfully predict the model. The calibration phase itself consists of four steps. These steps are coarse, fine, final, and forecast calibration, respectively. In the calibration phase, the goal is to select the optimal growth coefficients that affect four different growth rules. For this, the Brute Force Calibration method is used. These values, which are initially in the range of $0-100$, are narrowed after each calibration step and a single value is determined at the last step. Finally, the urban growth simulation is created in the prediction phase.

\subsection{Data Acquisition and Processing}

In Sancaktepe, the data belonging to previous years and needed by SLEUTH to create an urban growth simulation model are divided into time zones, taking into account the cadastral sheet production dates and zoning movements. As a result, four different time periods were determined: the years 1961, 1992, 2001 and 2014.

Cadastral data and land registry records were used as sources in the preparation of land cover, settlement, and transportation data. The slope and shaded relief data were produced with the digital elevation model (DEM) obtained from the General Directorate of Mapping.

The first facility of the regions within the boundaries of Sancaktepe started in the 1950s, and 36 maps were produced in different scales and coordinate systems in line with the possibilities of 1950-1980 (Ayazli \& Baslik, 2016). The second period covers the years 1987-1993, and during this period 58 cadastral maps were prepared in the local coordinate system and in different scales. In the third period covering 1997-2003, a total of 83 cadastral maps were produced in the ED50 coordinate system (Yakup, 2018). In the fourth period, the current cadastral base map produced in the ED50 coordinate system of October 2014 was used in a digital environment.

In the study, more than 70,000 parcel data from archival studies from different years were organized in a GIS environment and attribute information was entered through land registry data.

The input data of the model must be produced to certain standards. The standards for all data types are 8bit images in greyscale GIF format, they should be prepared in the common datum and coordinate system, in the same resolution and in accordance with the naming format. For the model to work, at least four periods of settlement, at least two periods of the transport network, two periods of land cover, and one period of slope, exclude, and shaded data are required (Gigalopolis, 2020). In this context, input data in the same coordinate system, the number of rows and columns was determined as 10 metres; 1184 rows, 1488 columns, 20 metres; 592 rows, 744 columns and 40 metres; 296 rows, 372 columns.

Land cover data were prepared for two periods: 1961 and 2014 (Figs. 2 and 3, Table 1).

Table 1. 1961-2014 Land Cover Classes.

\begin{tabular}{lllll}
\hline \begin{tabular}{l} 
Land Cover \\
\multicolumn{1}{c}{ Class }
\end{tabular} & $\begin{array}{l}\text { Pixel } \\
\text { Count }\end{array}$ & Rate (\%) & $\begin{array}{l}\text { Pixel } \\
\text { Count }\end{array}$ & Rate (\%) \\
\hline Urban & 2290 & 4 & 200,989 & 36.1 \\
Agriculture & 287,009 & 50 & 87,797 & 15.7 \\
Forest & 271,087 & 45.7 & 235.349 & 42.2 \\
Open Land & 15,774 & 0.3 & 33,379 & 6 \\
\hline
\end{tabular}

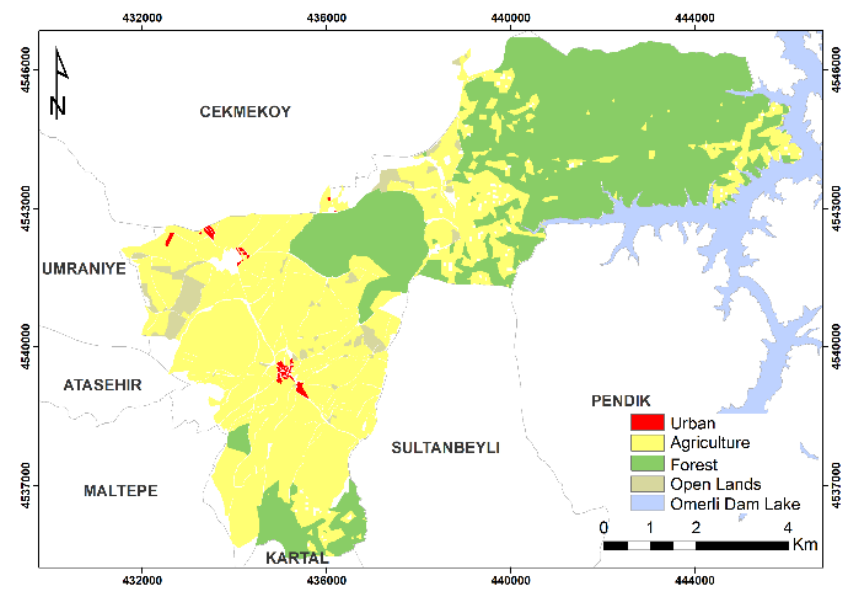

Figure 2. Sancaktepe land cover in 1961. 
Settlement data was produced for 1961, 1992, 2001 and 2014. In this context, the urban mass expanded by approximately 36\% from the starting year of 1961 until the last control year 2014 (Table 2 and Fig-4).

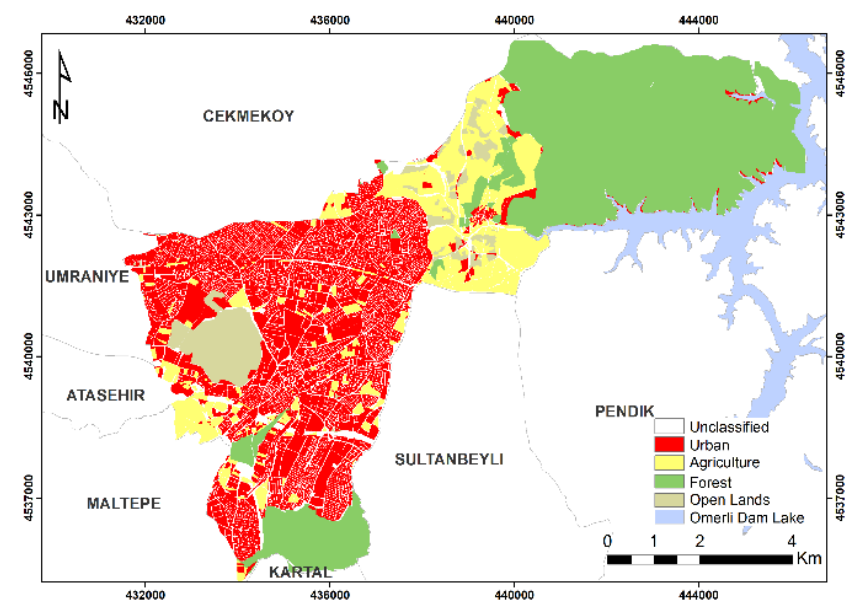

Figure 3. Sancaktepe land cover in 2014.

Specifying the parcel type as "land" in the land registry or cadaster records indicates that the parcel is a development parcel. Zoning parcels are formed as a result of land and plot arrangements. These parcels have been turned into forms suitable for construction and their intended use is in this direction. Parcels that do not have any construction are also included in the settlement data. In short, the construction criteria are not taken into account in the settlement data.

Transport network data from 1961, 1992, 2001, and 2013 are produced from cadastral sheets. In addition, road data for the year 2006 was obtained readily and included in the model. Transportation networks are weighted in four different classes according to the importance of roads.

The TEM highway, which divides Samandira into two, the Sile Highway, the dam road connecting Yenidogan and Sarigazi, and the Pasakoy connection roads of the Northern Marmara Motorway Project have been determined as the first-degree transportation network because they are the most important of these roads, and carry much of the traffic of the district. Various boulevards and main streets in the region are specified as second-degree transportation networks. Third and fourth-degree networks represent side streets or village roads (Table 3).

Table 2. Settlement mass by years.

\begin{tabular}{ccc}
\hline Year & Pixel Count & Rate (\%) \\
\hline 1961 & 4,102 & 0.7 \\
1992 & 35,576 & 6 \\
2001 & 154,160 & 28 \\
2014 & 201,320 & 36 \\
\hline
\end{tabular}

Table 3. Total lengths of roads according to their levels and period.

\begin{tabular}{lllll}
\hline \multirow{2}{*}{ Period } & \multicolumn{4}{c}{ Level of Transportation Network } \\
& $1(\mathrm{~km})$ & $2(\mathrm{~km})$ & $3(\mathrm{~km})$ & $4(\mathrm{~km})$ \\
\hline 1961 & 6.08 & - & 29.71 & 85.71 \\
1992 & 20.57 & 19.96 & 65.97 & 124.33 \\
2001 & 28.29 & 107.77 & 95.10 & 114.65 \\
2006 & 27.71 & 106.98 & 95.20 & 114.62 \\
2013 & 35.58 & 215.26 & 446.13 & - \\
\hline
\end{tabular}
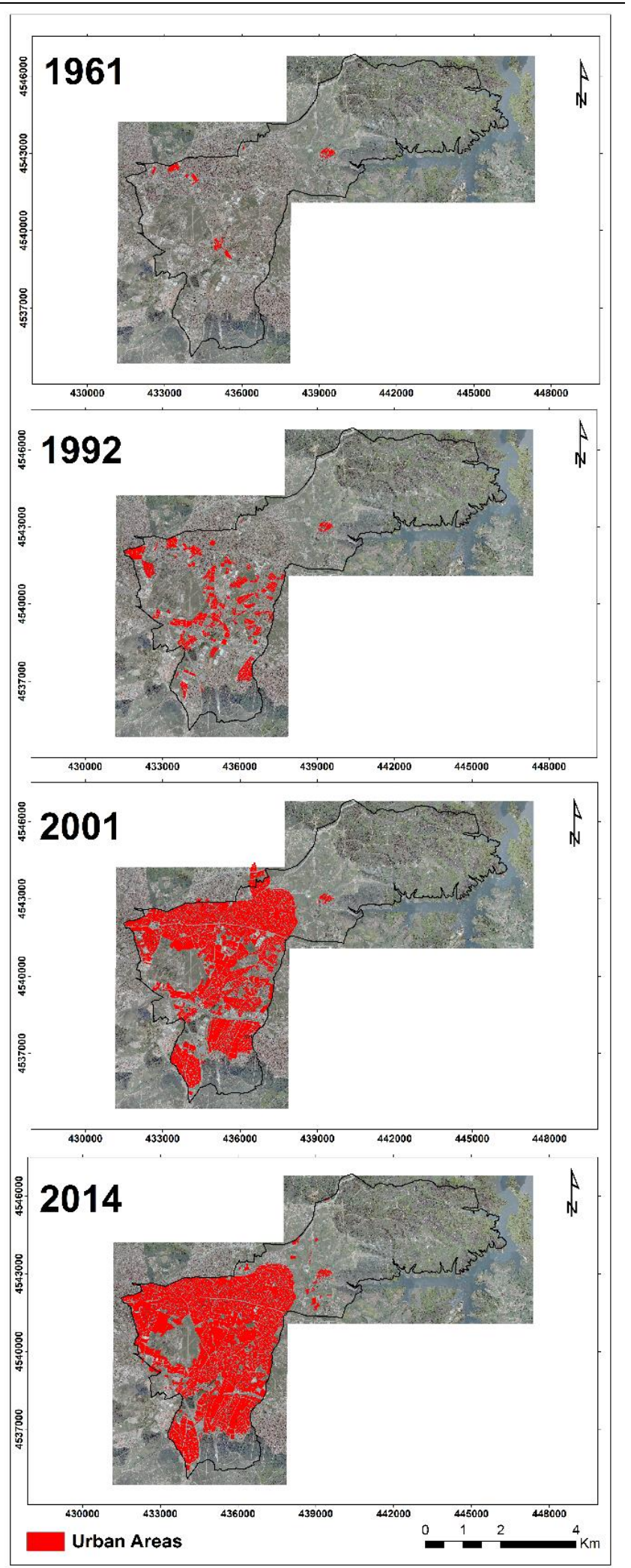

Figure 4. Urban areas by period. 
Past behaviours in land cover changes, zoning movements in the region, natural protection zones, and places with high agricultural potential are organized within the excluded data. In the scenario created, it is assumed that the ongoing land cover trends will continue. In this direction, temporal change analysis was conducted between 1961-2014 and the transformation percentage of residential areas was determined as $13 \%$. The transformation of forest areas is $13 \%$. For this reason, assuming that forest areas are preserved at this rate, the complement of $13 \%$ was taken and pixel values of forests were weighted as $87 \%$ in the excluded data (Fig $5)$.

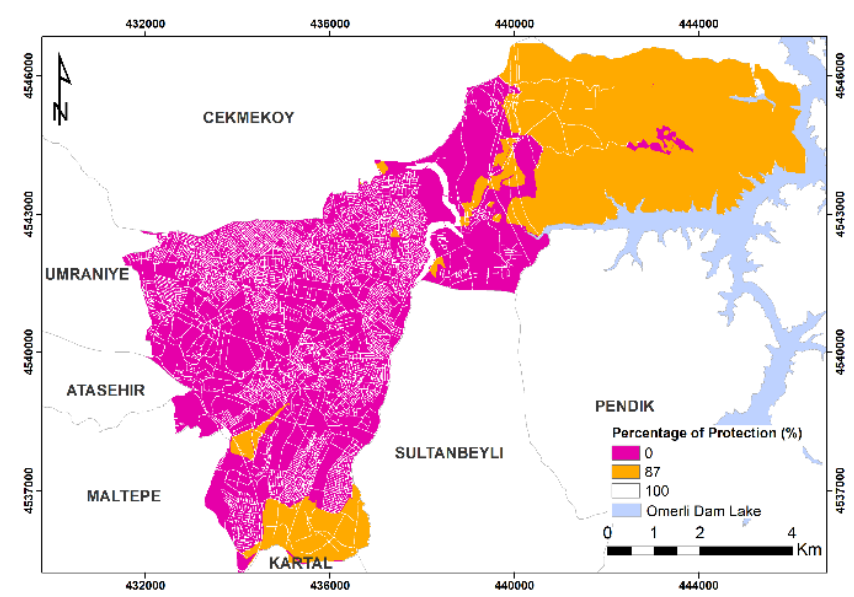

Figure 5. Excluded input data.

\section{RESULTS}

It was observed that all five coefficients were effective in the urban growth of Sancaktepe. The coefficient values obtained are shown in Table 4. Three different coefficient values are calculated as close to 100 , which is the ceiling value. Among the coefficients, the highest values were the diffusion, spread and breed coefficients. High values of the coefficients indicate that the four growth rules are intensely effective. The diffusion coefficient indicates random growth, the breed coefficient indicates new propagation-centred growth, and the road gravity coefficient indicates that path-efficient growth is effective.

According to the results of the urban growth simulation, urban growth rates of $32 \%$ from 2014 to $2030,25 \%$ from 2030 to 2050 , and $1 \%$ between the years 2050-2070 have been determined. This means that in total there is an urban growth rate of $21 \%$.
In this context, when the trend of growth rates is examined, the urban growth rate, which increased from 2014 to 2030, will accelerate further between 2030 and 2050 . In the 2050-2070 interval, the growth rate begins to slow down.

The direction of growth was determined to be predominantly towards the northeast of the study area (Pasakoy). However, urban growth has also been observed in the Kuzudere state forest in the south and in the open land area in the inner part of Sarıgazi (Fig 7).

Amounts and rates of land cover changes in Sancaktepe were obtained by analysis of the changes. Accordingly, it was calculated that $82 \%$ of agricultural land, $2 \%$ of forest areas, and $84 \%$ of open land can be converted into residential areas (Fig 6).

As expected, due to the preserved percentages of forest areas, it is concluded that the forest is protected to a large extent by not experiencing much urbanization. However, the city, which has spread to the forest border of Pasakoy, has caused destruction to the forest periphery and the land cover function to change, as dispersed in the inner parts. This behaviour is valid not only for the area of Pasakoy but also for the Kuzudere state forest in the region of Samandira.

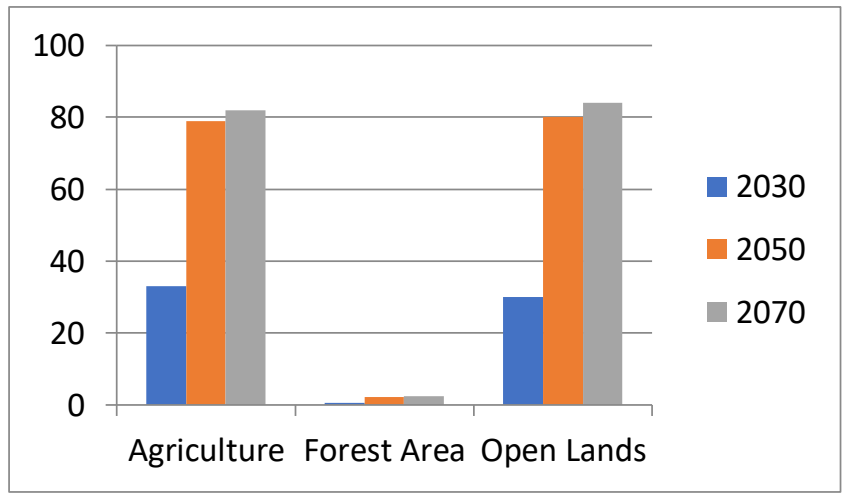

Figure 6. Percentage conversion of land cover classes to settlement

The kappa statistic was calculated for the predicted land cover image in 2020 in order to calculate the success of the scenario created. Fifty trial samples for each class of land cover were produced to determine the accuracy of the assessment by calculating the kappa statistic. The trial samples were compared with Google Earth images and the kappa value was estimated as $89 \%$.

Table 4. Model Calibration Stages and Calculated Coefficients.

\begin{tabular}{|c|c|c|c|c|c|c|c|}
\hline \multirow{3}{*}{ Coefficient Name } & \multirow{2}{*}{\multicolumn{2}{|c|}{$\begin{array}{c}\text { Coarse Calibration } \\
\text { Number of iterations }=8\end{array}$}} & \multirow{2}{*}{\multicolumn{2}{|c|}{$\begin{array}{c}\text { Fine Calibration } \\
\text { Number of iterations }=10\end{array}$}} & \multirow{2}{*}{\multicolumn{2}{|c|}{$\begin{array}{c}\text { Final Calibration } \\
\text { Number of iterations }=10\end{array}$}} & \multirow{3}{*}{$\begin{array}{c}\text { Calculated } \\
\text { Coefficient } \\
\text { Values }\end{array}$} \\
\hline & & & & & & & \\
\hline & Range & Step & Range & Step & Range & Step & \\
\hline Dispersion & $0-100$ & 25 & $75-100$ & 5 & $100-100$ & 1 & 100 \\
\hline Breed & $0-100$ & 25 & $100-100$ & 1 & $100-100$ & 1 & 100 \\
\hline Spread & $0-100$ & 25 & $100-100$ & 1 & $100-100$ & 1 & 100 \\
\hline Slope & $0-100$ & 25 & $25-100$ & 15 & 85-100 & 3 & 94 \\
\hline Road Gravity & $0-100$ & 25 & $25-100$ & 15 & $25-100$ & 15 & 85 \\
\hline
\end{tabular}



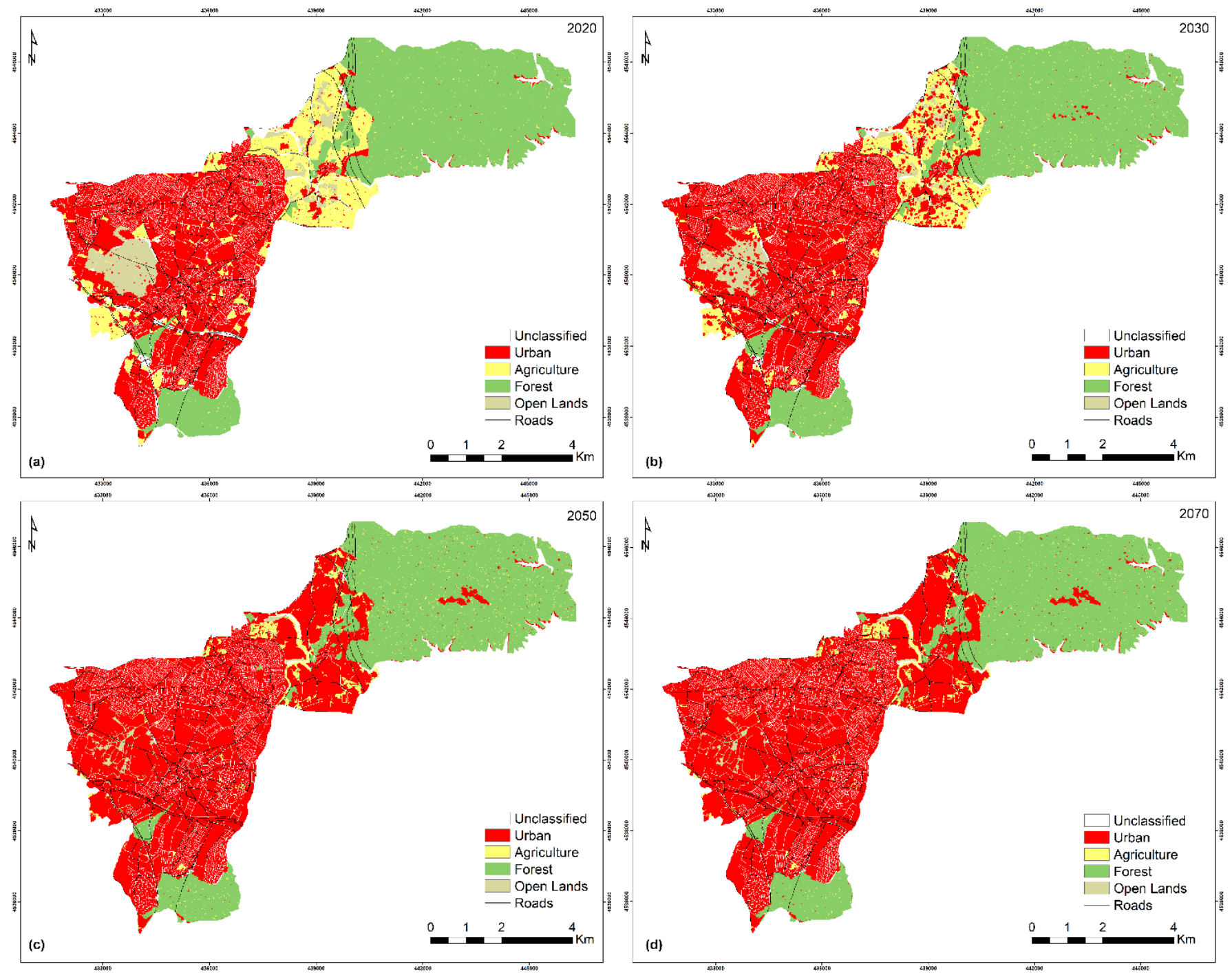

Figure 7. Land cover prediction maps (a for 2020, b for 2030, c for 2050, d for 2070)

\section{CONCLUSION}

Rapid population growth in Sancaktepe has caused urban growth. Therefore, an urban growth model that can describe land cover and assist local government decision-making is needed to evaluate the potential effects of growth policies. In this direction, the CA-based SLEUTH model has been preferred for modelling urban growth in Sancaktepe.

Very intense urbanization has been experienced in Sancaktepe between 1990 and 2000. In particular, the town of Yenidogan has taken its current urban form by dividing it into 6,456 parcels from a single 441-hectare special forest type parcel. Intensive urbanization in Yenidogan ensured the continuation of its rural character by protecting Pasakoy and forest areas. Due to its proximity to Yenidogan and the land stock in the area, this study focused specifically on Pasakoy and its surrounding areas.

When the parcels of Yenidogan, which is the neighbouring town of Pasakoy, are examined geometrically, it is observed that it has spread like an oil stain towards Pasakoy in a northeast direction. However, due to a stream crossing on the border of Pasakoy and Yenidogan, and a rehabilitation project belonging to this stream, urbanization in Pasakoy takes place centrally and in parts.

It has been determined that almost all of the agricultural land in the Pasakoy and Samandira regions can be converted into residential areas. Intense urban growth has not been observed in areas protected from urbanization such as the Omerli Basin Protection Zone and Kuzudere forest. A trend towards urban growth has been observed, particularly in Pasakoy. It has also been observed, to a lesser extent than Pasakoy, in the former military area in the Samandira and Sarigazi regions. Accordingly, changes in land cover triggered by urban growth took place in these regions. It has been concluded that open land and agricultural land can be largely urbanized.

The kappa value was estimated as $89 \%$ for the year 2020 and it can be said that the generated scenario is close to real. According to Figure 7a, urbanization influences created by motorways in the forest areas have been at a minimum level between 2014-2020. However, the trend towards urbanization may increase in Pasakoy after 2030 if further precautions are not taken. 


\section{ACKNOWLEDGEMENT}

The data used in this paper were generated within the scope of the TUBITAK 112K469 numbered project.

\section{Author contribution}

Ahmet Emir Yakup: Data curation, Software, WritingOriginal draft preparation, Visualization, Investigation, Writing-Reviewing and Editing. İsmail Ercüment Ayazlı: Conceptualization, Methodology, Validation, Writing-Reviewing and Editing.

\section{Conflicts of interest}

The authors declare no conflicts of interest.

\section{REFERENCES}

Akin A, Clarke K C \& Berberoglu S (2014). The impact of historical exclusion on the calibration of the SLEUTH urban growth model. International Journal of Applied Earth Observation and Geoinformation, 27(PARTB), 156-168. https://doi.org/10.1016/j.jag.2013.10.002

Al-Awadhi T (2007). Monitoring and Modeling Urban Expansion Using GIS \& RS: Case Study from Muscat, Oman. https://doi.org/10.1109/URS.2007.371790

Ayazli I E (2019). An Empirical Study Investigating the Relationship between Land Prices and Urban Geometry. ISPRS International Journal of GeoInformation, 8 , 457. https://doi.org/10.3390/ijgi8100457

Ayazli I E \& Baslik S (2016). Creating Simulation Model of the Relationship between the Ownership Pattern and Urban Growth; Project Report.

Ayazli I E, Gul F K, Baslik S, Yakup A E \& Kotay D (2019). Extracting an Urban Growth Model's Land Cover Layer from Spatio-Temporal Cadastral Database and Simulation Application. Polish Journal of Environmental Studies, 28(3), 1063-1069. https://doi.org/10.15244/pjoes/89506

Ayazli I E, Kilic F, Lauf S, Demir H \& Kleinschmit B (2015). Simulating urban growth driven by transportation networks: A case study of the Istanbul third bridge. Land Use Policy, 49, 332-340. https://doi.org/https://doi.org/10.1016/j.landusep ol.2015.08.016

Aydin B (2010). Identification of ecological criteria for the greenfield development and adaptation of these criteria within current city planning policies: Ömerli waterbasin-Sancaktepe case study. Istanbul Technical University.

Batty M (2009). Urban Modeling. In International Encyclopedia of Human Geography (pp. 51-58). https://doi.org/10.1016/B978-0080449104.01092-0

Benenson I \& Torrens P (2004). Geosimulation: Automata-based modeling of urban phenomena. John Wiley \& Sons.

Bihamta N, Soffianian A, Fakheran S \& Gholamalifard M (2014). Using the SLEUTH Urban Growth Model to Simulate Future Urban Expansion of the Isfahan
Metropolitan Area, Iran. Journal of the Indian Society of Remote Sensing, 43 https://doi.org/10.1007/s12524-014-0402-8

Candau J \& Clarke K C (2000). Probabilistic Land Cover Transition Modeling Using Deltatrons. 2000 URISA Annual Conference, Orlando.

Chaudhuri G \& Clarke K C (2013). The SLEUTH Land Use Change Model : A Review. The International Journal of Environmental Resources Research, 1(1), 88-104.

Clarke K \& Gaydos L (1998). Loose-coupling a cellular automaton model and GIS: long-term urban growth prediction for San Francisco and Washington/Baltimore. International Journal of Geographical Information Science, 12(7), 699-714. https://doi.org/10.1080/136588198241617

Clarke K, Hoppen S \& Gaydos L (1997). A Self-Modifying Cellular Automaton Model of Historical Urbanization in the San Francisco Bay Area. Environment and Planning B: Planning and Design, 24(2), 247-261. https://doi.org/10.1068/b240247

Dennunzio A, Formenti E \& Kurka P (2012). Cellular Automata Dynamical Systems.

Di Lena P \& Margara L (2008). Computational complexity of dynamical systems: The case of cellular automata. Inf. Comput., 206, 1104-1116.

EEA (2016). Urban Sprawl in Europe: Joint EEA-FOEN.

Foot D (2017). Linear urban models (pp. 137-173). https://doi.org/10.4324/9781315105307-6

Gandhi S \& Suresh V (2012). Prediction of Urban Sprawl in Hyderabad City using Spatial Model, Remote Sensing and GIS Techniques. International Journal of Scientific Research, 1, 80-81. https://doi.org/10.15373/22778179/JUL2012/25

Gigalopolis (2020). Project Gigalopolis Web Page. USGS. http://www.ncgia.ucsb.edu/projects/gig/

Goldstein N C, Candau J T \& Clarke K C (2004). Approaches to simulating the "March of Bricks and Mortar." Computers, Environment and Urban Systems, 28(1), 125-147. https://doi.org/https://doi.org/10.1016/S01989715(02)00046-7

Grimm V, Revilla E, Berger U, Jeltsch F, Mooij W M, Railsback S F, Thulke H H, Weiner J, Wiegand T \& DeAngelis D L (2005). Pattern-oriented modeling of agent-based complex systems: Lessons from ecology. In Science. https://doi.org/10.1126/science.1116681

Herold M, Goldstein N C \& Clarke K C (2003). The spatiotemporal form of urban growth: measurement, analysis and modeling. Remote Sensing of Environment, 86(3), 286-302. https://doi.org/https://doi.org/10.1016/S00344257(03)00075-0

Huanga J, Zhangb J \& Luc X (2008). Applying SLEUTH For Simulating and Assessing Urban Growth Scenario Based on Time Series TM Images : Referencing to a Case Study of Chongqing, China.

Jantz C A, Goetz S J \& Shelley M K (2004). Using the SLEUTH urban growth model to simulate the impacts of future policy scenarios on urban land use in the Baltimore-Washington metropolitan area. Environment and Planning B: Planning and Design, 31(2), 251-271. https://doi.org/10.1068/b2983 
Saadani S, Laajaj R, Maanan, M, Rhinane, H \& Aaroud A (2020). Simulating spatial-temporal urban growth of a Moroccan metropolitan using CA-Markov model. Spatial Information Research. https://doi.org/10.1007/s41324-020-00322-0

Sancaktepe (2010). 1/1000 Scale Sancaktepe Implementary Development Plan Sancaktepe Municipality.

Sancaktepe (2020). Sancaktepe Municipality Web Page. http://www.sancaktepe.bel.tr/tr/cografi-durumu

Sandamali S, Kantakumar L \& Sivanantharajah S (2018). Remote Sensing Data and SLEUTH Urban Growth Model: As Decision Support Tools for Urban Planning. Remote Sensing Data and SLEUTH Urban Growth Model, 28, 274-286. https://doi.org/10.1007/s11769-018-0946-6

Satterthwaite D (2005). The Scale of Urban Change Worldwide 1950-2000 and Its Underpinnings. International Institute for Environment and Development.

https://books.google.com.tr/books?id=M47aajCtKr8 C

Silva E A \& Clarke K C (2005). Complexity, emergence and cellular urban models: lessons learned from applying SLEUTH to two Portuguese metropolitan areas. European Planning Studies, 13(1), 93-115. https://doi.org/10.1080/0965431042000312424

Silva E \& Clarke K (2002). Calibration of the SLEUTH urban growth model for Lisbon and Porto, Portugal. Computers, Environment and Urban Systems, 26, 525552. https://doi.org/10.1016/S01989715(01)00014-X

Tobler W R (1970). A Computer Movie Simulating Urban Growth in the Detroit Region. Economic Geography, 46, 234-240. https://doi.org/10.2307/143141
TUIK (2020). Turkish Statistical Institute Web Page. Turkish Statistical Institute. https://biruni.tuik.gov.tr/medas /?kn=95\&locale=tr

Verburg P H (2006). Simulating feedbacks in land use and land cover change models. Landscape Ecology, 21(8), 1171-1183. https://doi.org/10.1007/s10980-0060029-4

Watkiss B M (2008). The SLEUTH urban growth model as forecasting and decision-making tool. Stellenbosch University.

Xie Y, Ma A \& Wang H (2010). Lanzhou urban growth prediction based on Cellular Automata. In 2010 18th International Conference on Geoinformatics, Geoinformatics 2010. https://doi.org/10.1109/GEOINFORMATICS.2010.5 567556

Yakup A E (2018). Research the relationship between the ownership pattern and urban growth. Sivas Cumhuriyet University.

Yi W \& He B (2009). Applying SLEUTH for simulating urban expansion of Beijing. In Proceedings - 2009 International Forum on Information Technology and Applications, IFITA 2009 (Vol. 2). https://doi.org/10.1109/IFITA.2009.543

Zhang Z, Jiang L, Peng R \& Yin Y (2010). The spatiotemporal change of urban form in Nanjing, China: Based on SLEUTH and spatial metrics analysis. 2010 18th International Conference on Geoinformatics, $1-5$. https://doi.org/10.1109/GEOINFORMATICS.2010.5 567753 